Article

\title{
Can High-Tech Ventures Benefit from Government Guanxi and Business Guanxi? The Moderating Effects of Environmental Turbulence
}

\author{
Dejin Su ${ }^{1,2}$, Qixia Du ${ }^{3}$, Dongwon Sohn ${ }^{4, *}$ and Libo $\mathrm{Xu}^{1}$ \\ 1 School of Business Administration, Nanjing Audit University, \# 86, Yushan West Road, Jiangpu Street, \\ Pukou District, Nanjing 211815, China; sudejin@nau.edu.cn (D.S.); xuboli@nau.edu.cn (L.X.) \\ 2 School of Business, Nanjing University, \# 22, Hankou Road, Gulou District, Nanjing 210093, China \\ 3 School of Health Economics and Management, Nanjing University of Chinese Medicine, \# 138, Xianlin Road, \\ Qixia District, Nanjing 210023, China; duqixia@njucm.edu.cn \\ 4 College of Business Administration, Inha University, \# 253 Yonghyun-Dong, Nam-Gu, \\ Incheon 402751, Korea \\ * Correspondence: sohndw@inha.ack.kr; Tel.: +82-32-860-7730
}

Academic Editors: Malin Song and Marc A. Rosen

Received: 20 October 2016; Accepted: 13 January 2017; Published: 19 January 2017

\begin{abstract}
The construct of guanxi has become an interesting topic for analyzing how to do business more effectively and successfully in China's economic transition period. Drawing on the guanxi strategy theory, this study examines when government guanxi (guanxi with the government and its officials) and business guanxi (guanxi with the business sectors) matter to new venture performance under two typical turbulent environments (institutional turbulence and market turbulence). According to empirical results using original data from 146 new ventures in clusters driven by China's local governments, both government guanxi and business guanxi were positively related to new venture performance, and market turbulence was an important contextual factor influencing performance benefits of guanxi. However, the results reveal no moderating effects of institutional turbulence on direct relationships. Furthermore, the study provides a better conceptual and empirical understanding of why market turbulence is a double-edged sword for performance implications of guanxi in the rapidly changing business environment.
\end{abstract}

Keywords: government guanxi; business guanxi; institutional turbulence; market turbulence; new venture performance

\section{Introduction}

As noted in the literature, doing business in Western countries focuses mainly on "what you know" and "what you are good at", indicating that firms need to invest substantial resources in developing various firm capabilities such as technological, marketing, learning, and management capabilities. However, doing business in China often needs to focus on "whom you know" and "who can help you", indicating that firms need to invest resources in developing and maintaining effective formal or informal connections with appropriate individuals or organizations [1-4]. Such connections or ties are referred as "guanxi", which consists of "guan" (gate) and "xi" (tie). Guanxi reflects the nature and characteristics of the social progress or human life of China's Confucian society over the last two millennia $[5,6]$. To date, guanxi is an important research topic in strategic management and entrepreneurship to examine how business can be done more effectively and successfully in contemporary China.

As a centralized country, China consistently focuses on shifting from a planned economy to a market-based economy since the start of its openness and economic reform in 1978. On the one hand, 
the market is expected to play a dominant role in resource allocation and economic growth and thus can facilitate job creation and income growth [7]. It indicates that firms should establish and expand their guanxi connections with business sector, such as primary suppliers, customers, cooperators, and even rivals. For instance, having good guanxi connections with suppliers may help a focal firm much easily obtain low-cost materials with acceptable quality. In this respect, it seems that industries tend to be much less affected by political systems and government policies in a market-based economy than in a planned one. On the other hand, however, the Chinese government still has strong "soft power" to regulate the development of an industry [8]. Moreover, the government can promote or hinder industrial development and business operations by enacting a series of business policies in economic transition period $[9,10]$. Consequently, this study argues that both government guanxi (guanxi with the government and its officials) and business guanxi (guanxi with the business sector) may be two antecedents of doing business in China.

In addition, previous literature has shown that performance implications of guanxi (or network) are contingent on environmental factors. As known, China is experiencing economic transition which leads the business environment to undergo volatile turbulence in terms of its institutions, markets, technologies, and culture [11,12]. In this regard, potential effects of different types of guanxi on business performance may vary across a rapidly changing business environment. The present study considers two typical guanxi types (government guanxi and business guanxi) under two typical business environments (institutional turbulence and market turbulence) to fill two important gaps in the literature. First, with empirical evidence from a survey of 146 new ventures located in government-driven high-tech clusters, the study examines general effect of government guanxi on new venture performance. Firms can undoubtedly benefit from developing and keeping good guanxi connections with the business sector, because a strong firm-business interaction enables firms to be embedded in a business network and establish legitimacy as quickly as possible [13]. However, the relationship between government guanxi and business performance remains unclear and thus has been a topic of an ongoing debate. Some studies have argued that developing government guanxi may help firms establish institutional confidence and obtain sufficient government resources, whereas others have failed to find any direct effects of government guanxi (or political ties) on business performance $[8,10]$. A literature review reveals differences in research samples between these two competing findings, with the former focusing on government-sponsored firms, whereas the latter, on high-tech firms. Given that the present study's sample is from government-driven high-tech clusters, it is confused whether government guanxi is critical to new venture performance.

Second, the study investigates whether contextual factors such as environmental turbulence are contingent on performance implications of guanxi. Although previous studies focusing on the Chinese context reveal that some contingencies (i.e., ownership, location, and firm size) may alter the value of guanxi, there is an apparent gap in the literature in whether environmental turbulence can be seen as a critical moderator [14]. To answer this question, this study focuses on two typical environmental conditions (institutional turbulence and market turbulence) that may reflect the nature and characteristics of China's economic transition. More specially, it examines their respective moderating effects on the relationship between government guanxi (or business guanxi) and new venture performance.

The rest of this paper is organized as follows: Section 2 draws on guanxi strategy theory to suggest that guanxi is a dominant determinant of doing business in China but that environmental turbulence can foster or impede outcomes of different types of guanxi. Based on a literature review and a theoretical analysis, the section develops six hypotheses about relationships between guanxi, environmental turbulence, and new venture performance. Section 3 describes research sample, data collection method, research model, and measurement method. Section 4 presents the analysis steps and empirical results. Section 5 discusses the research findings, theoretical contributions, managerial implications, limitations, and future research directions, and Section 6 concludes. 


\section{A Theoretical Review and Hypothesis Development}

\subsection{Guanxi Strategy Theory}

Social network theory, developed by Western management scholars, has been widely applied to investigate the importance of personal or organizational connections in business activities $[15,16]$. In the context of Chinese management, some scholars also employ social network theory to analyze how personal or organizational connections affect business operations [14,17]. However, general connections can not reflect the nature and characteristics of connection ties in Confucian societies (e.g., Mainland China, Taiwan, and Hong Kong). In this regard, guanxi that goes deeper than connection has attracted a great attention from scholars and practitioners [18]. Traditionally, guanxi is a deeply ingrained institution that highlights the interrelationships between family members, relatives, friends, and other significant others. Family relations (qinyuan), geographic relations (diyuan), religious relations (shenyuan), business relations (yeyuan), and product relations (wuyuan) are the most frequent types of guanxi that are often used by sociology and management scholars to identify a person's social status. This indicates that guanxi traditionally originates from the basis of special roots and refers to personal connections at the individual level.

From the perspective of strategic management, guanxi is often regarded as a particular and inimitable strategic resource that can help firms develop and maintain their competitive advantage [19-21]. As mentioned earlier, guanxi reflects the Chinese contextual notion and the way that people can do business more effectively and successfully. Therefore, some scholars from both Western countries and China have made efforts since the late 1990s to develop guanxi strategy theory to examine the relationship between guanxi and firm performance in a more effective manner [22,23]. Guanxi strategy theory suggests that building and using guanxi connections may help firms strengthen business performance in China's economic transition period [1]. That is because the degree of guanxi connections may affect the flow of resources and interactions with the firm-task environment, thereby helping develop a competitive advantage in a rapidly changing business environment $[14,24]$. Similarly, Su et al. (2003) [25] precisely pointed out that, in comparison to large firms, small- and medium-sized enterprises are more likely to benefit from guanxi under scarce resources. Furthermore, they suggested that guanxi can be regarded as a strategic tool which can increase the efficiency and effectiveness of doing business in China. In the field of entrepreneurship, Guo and Miller's (2010) [2] work suggested that guanxi connections play a significant role across entrepreneurial processes. First, during firm creation, guanxi ties with family members and relatives may provide initial funding or psychological support for entrepreneurs [4]. Second, during early firm growth, guanxi ties with critical stakeholders such as government officials, business partners, capitalists, and primary customers may help new ventures become more effectively embedded in a network to gain an industrial or social division. Third, during stable firm growth, guanxi ties with various individuals and organizations from multiple backgrounds may help new ventures consistently exploit business opportunities and market potential to realize sustainable growth. Su and Sohn (2015) [23] offered additional theoretical perspectives on the role of guanxi in entrepreneurship, through which new ventures often obtain important information and critical resources by using their guanxi ties with important individuals or organizations. They also emphasized that the mutual trust originating from guanxi ties can help new ventures create accessing routines to entrepreneurial resources. In this regard, the present study argues that a utilization of guanxi strategy theory may enhance our understanding of how new ventures leverage different types of guanxi under different turbulent environmental conditions.

\subsection{Government Guanxi, Business Guanxi and New Venture Performance}

\subsubsection{Government Guanxi and New Venture Performance}

Studies of Chinese management in the last few decades may convince entrepreneurs and managers that building and maintaining stronger guanxi connections with the government and its officials has 
significant effects on business creation and operation. First, the Chinese government can use its "soft power" to effectively regulate industries and business activities to realize government goals with respect to the economy or society, such as jobs' creation, wealth generation, and economic growth [8]. Second, new ventures need government to provide various supports, such as institutional infrastructure, industrial policies, and even taxation preferences. In this respect, the Chinese government may be a reliable partner and the goals of governments and firms are cooperative rather than competitive.

In addition, recent empirical studies have also asserted the importance of government guanxi in new venture performance. For instance, Guo and Miller [2] found that new ventures with good guanxi with the government may enhance their ability to access entrepreneurial resources and be more confident in doing business in China. Using a sample of 55 biopharmaceutical high-tech firms in China, Wang and Lestari [26] precisely pointed out that government guanxi is positively related to market entry success because the Chinese government "has the authority to approve projects, allocate resources, and arrange financing and distribution." From the resource-based view, Chen et al. [27] suggested that government guanxi has a significant effect on information accessibility, thereby influencing new venture creativity and social reputation. In light of the importance of the Chinese government in industrial development and market restructuring, this study deems that new ventures should maintain good guanxi connections with government and its officials to obtain more institutional resources or confidence to operate business more smoothly in China. In this regard, the following hypothesis is proposed:

Hypothesis 1. General speaking, government guanxi has a significant positive effect on new venture performance.

\subsubsection{Business Guanxi and New Venture Performance}

Precisely speaking, the market of Mainland China is a huge and complex web of business guanxi [25]. It indicates that doing business in China requires effective interactions with a particular business network of various stakeholders such as customers, suppliers, partners, and rivals, which is often defined as "business guanxi" [10,28]. Guanxi strategy theory points out that Chinese businessmen often use guanxi to control or influence their business partners because guanxi potentially fosters mutual trust for sharing market information, advice, and resources among network members. For instance, keeping good guanxi connections with important personals (e.g., top managers of business partners) or organizations (e.g., business partners) may make it more likely to provide industrial divisions and benefits [29]. Similarly, Cao et al. [13] argued that in a common business guanxi network, a firm can effectively interact with its business partners "in a particular way at a particular time for a particular price", leading to lower transaction costs and better performance. In sum, previous studies have suggested that investing in and using business guanxi can help a firm develop a strategic competitive advantage, ultimately strengthening its performance [30].

For new ventures, their survival and growth are greatly influenced by several important strategic factors such as building business legitimacy [31], looking for primary customers [13], promoting business transactions [32], and obtaining knowledge or technology support [23]. Guanxi strategy theory argues that these strategic needs are very closely related to the effective embeddedness of business guanxi $[1,23]$. This is because good business guanxi can help new ventures overcome their liability of newness and more effectively embed themselves in the industrial network to benefit from industrial divisions [33]. For example, new ventures can benefit from having good business guanxi with primary customers. First, primary customers may provide more targeted and effective advice for new ventures to develop products to better meet customers' needs, exploit market opportunities, or optimize supply chains. Second, primary customers can provide emotional support or confidence for new ventures to do business in an uncertain business environment with a high level of risk $[17,34]$. Therefore, it is common for new ventures to develop and use good guanxi connections with business 
sectors to do business more successfully when their strategic resources are scarce. In this regard, the following hypothesis is proposed:

Hypothesis 2. General speaking, business guanxi has a significant positive effect on new venture performance.

\subsection{Economic Transition: Market Turbulence and Institutional Turbulence}

Both social network theory and guanxi strategy theory point out that the value of guanxi (social capital) "varies across distinct environmental conditions" [35]. China's economic transition leads the business environment to experience turbulence in terms of its institutions, markets, and culture [10]. For entrepreneurship, a turbulent environment indicates that new ventures often face massive opportunities and challenges such as rapid changes in customer demands or preferences, institutional policies, and technological innovations [36]. Consequently, this study argues that benefits of guanxi are contingent on environmental turbulence. However, some studies [13] have argued that environmental turbulence impedes benefits of guanxi, whereas others [1] provide the opposite findings.

Given that government guanxi and business guanxi are two independent variables of the present study, we argue that institutional turbulence and market turbulence may be two important environmental contingency factors influencing the value of government guanxi and business guanxi. Therefore, it would be beneficial to take into account environmental turbulence for a better understanding of the nature of guanxi in the literature on Chinese management and its impact on doing business in China.

\subsubsection{Moderating Effects of Institutional Turbulence}

This study posits that institutional turbulence may be an important contingency factor moderating the relationship between government guanxi (or business guanxi) and new venture performance. Rapid changes in the political system establish many new rules or bring various constraints, which lead new ventures to distribute their finite resources to respond to these changes [36]. A high level of institutional turbulence indicates rapid and uncertain changes in government policies and legal institutions. At this time, the Chinese government and its officials may use "soft power" to have considerable influence on business operations [8]. Therefore, keeping and maintaining stronger guanxi connections with the government and its officials may help new ventures obtain institutional resources and enrich the resource base, which can strengthen business performance under a high level of institutional turbulence. However, building and maintaining stronger guanxi with the business sector may be counterproductive under a high level of institutional turbulence. That is because developing guanxi with primary customers, suppliers, and cooperators requires resource investment so that new ventures will have no enough resources to respond to the institutional changes.

On the other hand, the government tends to provide more service functions and fewer interference functions for business activities under a low level of institutional turbulence. It suggests that legal and institutional systems with respect to industries become stable and developed, indicating that the importance of government guanxi connections in doing business is likely to decline, but developing guanxi with business sectors may be more crucial for performance creation [10,14]. In this regard, the following hypotheses are proposed:

Hypothesis 3. Institutional turbulence has a positive moderating effect on the relationship between government guanxi and new venture performance.

Hypothesis 4. Institutional turbulence has a negative moderating effect on the relationship between business guanxi and new venture performance. 


\subsubsection{Moderating Effects of Market Turbulence}

This study posits that market turbulence acts as an important contingency factor moderating the relationship between government guanxi (or business guanxi) and new venture performance. A turbulent market environment indicates rapid changes in customer demands and preferences [37]. Under a turbulent market environment, new ventures may benefit from developing and maintaining good guanxi with business partners. First, having good guanxi with primary customers may help new ventures develop products more quickly and accurately to realize a first-mover advantage. Furthermore, existing customers can help new ventures find and establish connections with potential customers and new markets, which may be crucial for the survival of new ventures in a market with a low growth rate [34]. Second, having good guanxi with suppliers may help new ventures obtain lower-cost materials with acceptable quality, thereby providing products at lower and more competitive prices. In sum, the value of business guanxi in the creation of new ventures increases along with a turbulent market environment.

On the other hand, this study posits that developing and maintaining good guanxi with the government and its officials under a turbulent market environment have a negative effect on new venture performance. Previous studies have pointed out that the establishment and development of guanxi requires substantial resource investment. However, the resource base of new ventures is weak, so investing their resources in government guanxi may be a wrong strategic decision that may impede business performance creation. In addition, resources obtained from the government cannot facilitate or even damage business creation in a turbulent market [38]. In this regard, the following hypotheses are proposed:

Hypothesis 5. Market turbulence has a negative moderating effect on the relationship between government guanxi and new venture performance.

Hypothesis 6. Market turbulence has a positive moderating effect on the relationship between business guanxi and new venture performance.

\section{Methods}

\subsection{The Sample and Data Collection}

New ventures can be defined as small businesses that are invested in by individual(s) or group(s) with the expectation of the business operation bringing in financial or marketing gains for investors or entrepreneurs. It is widely acknowledged that new ventures make important contributions to economic growth and social progress [39]. Previous studies of strategic management have suggested that, in comparison to big and established firms, new ventures often face more severe survival challenges because of resource scarcity $[9,39,40]$. In this regard, a strategic dilemma regarding how to improve the survival ability of new ventures under the condition of resource scarcity has attracted great attention from scholars and practitioners over a long time. As noted earlier, guanxi strategy theory argues that government guanxi and business guanxi may help new ventures access to institutional or marketing resources and enrich their resource base to develop a competitive advantage [41]. However, contingency theory points out that the value of guanxi may be influenced by environmental turbulence [10]. In this regard, a better understanding of the effects of government guanxi (or business guanxi) on firm performance should take into account the context (ecology) of the organization.

This study conducts a quantitative approach. According to the literature, a questionnaire consisting of seven variables and some important demographic information was constructed, and the English questionnaire was translated into Chinese after some revisions to fit the Chinese context. To ensure smooth survey, two entrepreneurs of new ventures in government-driven high-tech clusters and two professors interested in the guanxi strategy and entrepreneurship were recruited to evaluate 
all items in the questionnaire. Based on their suggestions, some academic terms were replaced with easily understandable ones to help the respondents answer all questions more accurately.

To collect data, several government-driven high-tech clusters (covering Guangdong, Fujian, Zhejiang, Shanghai, and Jiangsu, which consistently made efforts to develop high-tech industries and a private economy in the last decade) were asked for their help in July 2015. Government-driven high-tech clusters were chosen as the investigation setting for two reasons: First, new ventures belonging to these clusters were assumed to accurately describe their connections (guanxi) to the government and its officials, which often support or guide them to stimulate local economic growth and technological progress [42]. Second, new ventures in these clusters actively engaged in market competition and industrial divisions and thus could accurately describe their connections (guanxi) to the business sector [43].

These clusters provided a list of 550 new ventures with detailed contact information. From December 2015 to May 2016, the Chinese version of the questionnaire was sent to these new ventures to ask for their participation in the survey. To ensure the reliability of firm-level data, we set two criteria. First, each respondent had to be a top manager who could accurately describe the firm's guanxi with the government (or the business sector). Second, two top managers of each firm were asked to complete the questionnaire [44]. To avoid common method bias, one manager answered predictor variables (government guanxi, business guanxi, institutional turbulence, and market turbulence), and the other answered outcome variable (new venture performance). However, they were required to answer control variables (firm age and size). Finally, 152 new ventures and 304 top managers agreed to participate in the survey and returned the questionnaire, including six incomplete responses. The sample size ranged from 5 to 200 employees, averaging 46.8 employees.

\subsection{The Research Model}

As shown in Figure 1, a research model was used to examine whether government guanxi (guanxi with the government and its officials) and business guanxi (guanxi with the business sectors) matter to new venture performance under two typical turbulent environments (institutional turbulence and market turbulence). And, we built an equation to describe the statistical relationships between five variables.

$$
\mathrm{NVP}=\alpha+\beta_{1} \mathrm{GG}+\beta_{2} \mathrm{BG}+\beta_{3} \mathrm{IT} \cdot \mathrm{GG}+\beta_{4} \mathrm{IT} \cdot \mathrm{BG}+\beta_{5} \mathrm{MT} \cdot \mathrm{GG}+\beta_{6} \mathrm{MT} \cdot \mathrm{BG}+\mathrm{e},
$$

where government guanxi (GG) and business guanxi (BG) are predictor variables; institutional turbulence (IT) and market turbulence (MT) are moderating variables; new venture performance (NVP) is a dependent variable; and e is the residual of the regression equation. In addition, $\beta_{3}, \beta_{4}, \beta_{5}$, and $\beta_{6}$ represent interaction effects.

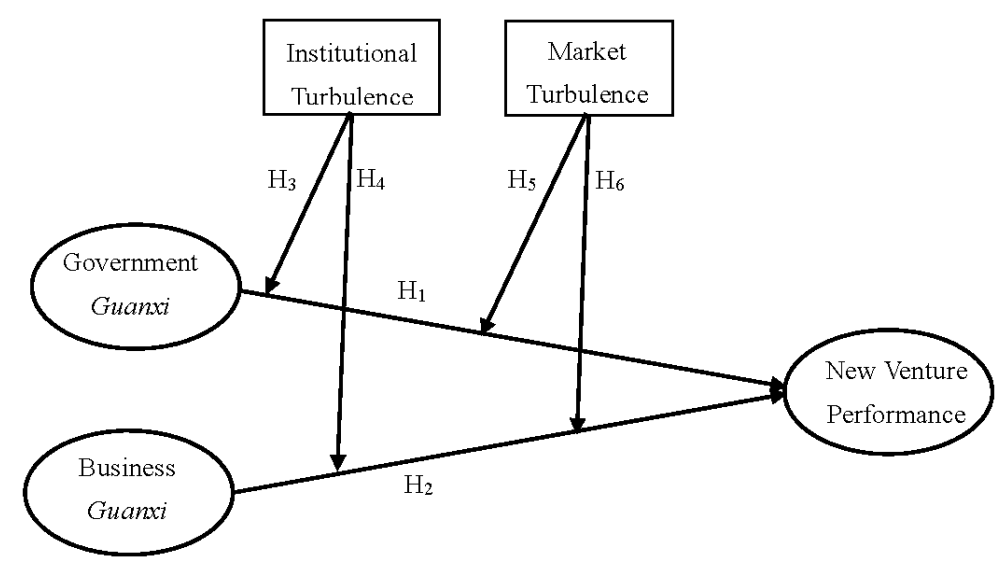

Figure 1. The theoretical model. 


\subsection{Measures}

\subsubsection{Government Guanxi}

The analysis employed Zhang's [45] seven-item scale to measure the nature and extent of government guanxi. All items were measured using a seven-point Likert-type scale from 1 (strongly disagree) to 7 (strongly agree). The respondents (top managers) were required to rate the guanxi value of their firms with respect to the local government and its officials (see as Table 1).

Table 1. A confirmatory factor analysis, standard estimates, and alpha values $(n=146)$.

\begin{tabular}{|c|c|}
\hline Variable Constructs and Measurement Items & Loading \\
\hline \multicolumn{2}{|l|}{ Government guanxi (Zhang, 2010) $(\alpha=0.79 ; \mathrm{CR}=0.93 ; \mathrm{AVE}=0.65)$} \\
\hline 1. The local government (or its officials) keeps its commitments to our managers and firm. & 0.85 \\
\hline 2. The local government (or its officials) does justice to our firm. & 0.80 \\
\hline 3. Our firm and local government (or its officials) trust each other. & 0.83 \\
\hline 4. Our firm and local government (or its officials) frequently communicate with each other. & 0.78 \\
\hline $\begin{array}{l}\text { 5. If necessary, our firm and local government (or its officials) often provide various } \\
\text { assistance to each other. }\end{array}$ & 0.87 \\
\hline 6. Our firm and local government (or its officials) often jointly solve some difficulties. & 0.82 \\
\hline $\begin{array}{l}\text { 7. Our firm has good guanxi connections with local government authorities } \\
\text { (e.g., government-sponsored banks, science and technology bureaus, industrial and } \\
\text { commercial bureaus, and tax bureaus) and their officials. }\end{array}$ & 0.69 \\
\hline \multicolumn{2}{|l|}{ Business guanxi (Zhang, 2010) $(\alpha=0.76$; CR = 0.88; AVE $=0.56)$} \\
\hline $\begin{array}{l}\text { 1. Primary business partners (e.g., customers, suppliers, and collaborators) consistently } \\
\text { keep their commitments to our firm. }\end{array}$ & 0.81 \\
\hline 2. Our firm and primary business partners frequently communicate with each other. & 0.77 \\
\hline 3. Primary business partners have good guanxi connections with top managers of our firm. & 0.79 \\
\hline $\begin{array}{l}\text { 4. Primary business partners often provide useful suggestions on improving the quality of } \\
\text { our products. }\end{array}$ & 0.76 \\
\hline $\begin{array}{l}\text { 5. Primary business partners and our firm often jointly overcome difficulties in } \\
\text { product development. }\end{array}$ & 0.67 \\
\hline 6. Primary business partners are willing to maintain long-term cooperation with our firm. & 0.69 \\
\hline \multicolumn{2}{|l|}{ Institutional turbulence (Johanson, 2002) $(\alpha=0.86 ; \mathrm{CR}=0.87 ; \mathrm{AVE}=0.62)$} \\
\hline 1. The local government acts in a way that leads us to great uncertainty. & 0.79 \\
\hline 2. It is hard to predict the impact of the political system on the market in this region. & 0.81 \\
\hline 3. It is difficult to foresee regional institutional changes. & 0.82 \\
\hline 4. Regional policies are relatively unstable. & 0.73 \\
\hline \multicolumn{2}{|l|}{ Market turbulence (Jaworski and Kohli, 1993) $(\alpha=0.87 ; \mathrm{CR}=0.90 ; \mathrm{AVE}=0.60)$} \\
\hline 1. In our kind of business, customers' product preferences change quite a bit over time. & 0.82 \\
\hline 2. Our customers tend to look for new products all the time. & 0.85 \\
\hline $\begin{array}{l}\text { 3. Our customers are sometimes very price sensitive, but on other occasions, prices are } \\
\text { less important. }\end{array}$ & 0.80 \\
\hline $\begin{array}{l}\text { 4. We are witnessing demand for our products and services from customers who never } \\
\text { bought them before. }\end{array}$ & 0.69 \\
\hline $\begin{array}{l}\text { 5. New customers tend to have product-related needs that are different from those of our } \\
\text { existing customers. }\end{array}$ & 0.78 \\
\hline 6. We cater to many of the same customers that we used to in the past. & 0.68 \\
\hline \multicolumn{2}{|l|}{ new venture performance (Anderson and Eshima, 2013) $(\alpha=0.84 ; C R=086 ; \mathrm{AVE}=0.68)$} \\
\hline 1. Sales growth & 0.81 \\
\hline 2. Market share growth & 0.84 \\
\hline 3. Employee growth & 0.82 \\
\hline
\end{tabular}

Notes: KMO (Kaiser-Meyer-Olkin) $=0.85$. 


\subsubsection{Business Guanxi}

The measurement of business guanxi followed a six-item scale also developed by Zhang [45]. All items were measured using a seven-point Likert-type scale ranging from 1 (strongly disagree) to 7 (strongly agree). The respondents were asked to rate their firms' guanxi value with respect to primary business partners, including customers, suppliers, and partners (see Table 1).

\subsubsection{Institutional Turbulence}

The four-item scale from Johanson [46] was used to measure institutional turbulence. The respondents were required to answer the range of change in new policies relevant to their business for the government's role in influencing a special market or industry, even a firm. More specifically, the degree of perceived institutional turbulence in the market was measured using four indicators: the extent to which the local government acts in a way that increases uncertainty; the difficulty in predicting the impact of the political system on the market in the region; the difficulty in foreseeing regional institutional changes; and the certainty of regional policies, particularly S\&T and monetary policies. These items were measured using a seven-point Likert-type scale from 1 (strongly disagree) to 7 (strongly agree).

\subsubsection{Market Turbulence}

Consistent with the literature, the six-item scale from Jaworski and Kohli [37] was used to measure market turbulence. The respondents were asked to describe the degree of perceived market turbulence based on the following factors: the rate of change in customers' product preferences; the rate of change in customers' new needs; the degree of price sensitivity; the ability to exploit new customers; the difference between new customers in product needs; and the ability to meet customer needs. The analysis focused on changes in market demand and customer preferences influencing a firm's market turbulence because these factors influence a firm's attitudes toward the use of its guanxi ties to access distinct resources and develop a competitive advantage in uncertain market conditions [44]. These items were measured using a seven-point Likert-type scale from 1 (strongly disagree) to 7 (strongly agree).

\subsubsection{New Venture Performance}

Three items were used to measure new venture performance. Consistent with the literature, the respondents were asked to address three major financial performance indicators for the last three years: sales growth, market share growth, and employee growth [47]. These three items were measured using a seven-point Likert-type scale 1 (much worse) to 7 (much better). The primary reason why subjective financial performance was used is that new ventures in China generally view objective financial information as a confidential matter and thus try to prevent it from becoming public. In addition, previous studies have shown that subjective financial indicators are more accessible than objective ones and can authentically and effectively reflect new venture performance [40].

\subsubsection{Control Variables}

Two variables were included as control variables: firm age and size. This is because previous studies have indicated that these two variables have the potential to impact the performance of new ventures [9]. The respondents were required to state the number of years and that of employees since the firm's establishment [47]. To a certain extent, firm age may reflect the degree to which new ventures are embedded in their business network, and firm size may reveal the resource base of new ventures.

\subsection{Assessment of Measures}

Consistent with the literature, we used AMOS 22.0 and the maximum likelihood estimation to conduct a confirmatory factor analysis (CFA) for assessing the reliability and validity of each 
construct [48]. Table 1 shows that the proposed five-factor model provided a good fit to the data. In addition, all alpha values exceeded 0.75 ; all CR (composite reliability) values exceeded 0.85; all average variance extracted (AVE) values exceeded 0.55 ; and the factor loading of each construct exceeded 0.65 , indicating sufficient convergent validity [49].

\section{Results}

\subsection{Analysis Steps}

To test the hypotheses about the relationship between government guanxi (or business guanxi) and new venture performance and examine whether this relationship varied between two typical turbulent environments (institutional turbulence and market turbulence), this study conducted a moderated hierarchical linear regression analysis (MHLRA) [50]. First, two control variables (firm age and size) were used to test their effects on new venture performance. Second, four constructs, namely government guanxi, business guanxi, institutional turbulence, and market turbulence, were included to test their main effects on new venture performance. Third, product terms representing the interaction between government guanxi (or business guanxi) and institutional turbulence (or market turbulence) were individually included to test individual moderating effects: Hypotheses 3-6 [51]. In this step, four product terms were produced, namely government guanxi $\times$ institutional turbulence, government guanxi $\times$ market turbulence, business guan $x i \times$ institutional turbulence, and business guan $x i \times$ market turbulence. Finally, we synchronously added the four product terms to check the robustness of the results.

\subsection{Hypothesis Tests and Results}

Means, standard deviations, and correlations between all variables in the model test are shown in Table 2. Pearson correlation coefficients between all variables were lower than $0.5(p<0.1)$, indicating that multicollinearity was not a serious concern.

Table 2. Means, standard deviations, and a correlation matrix $(n=146)^{\mathrm{a}, \mathrm{b}, \mathrm{c}}$.

\begin{tabular}{lccccccc}
\hline & $\mathbf{1}$ & $\mathbf{2}$ & $\mathbf{3}$ & $\mathbf{4}$ & $\mathbf{5}$ & $\mathbf{6}$ & $\mathbf{7}$ \\
\hline 1. Firm age & & & & & & & \\
2. Firm size & $0.22^{* *}$ & & & & & & \\
3. GG & -0.11 & $0.14^{*}$ & $\mathbf{0 . 6 5}$ & & & & \\
4. BG & $0.17^{*}$ & $0.26^{* *}$ & $0.32^{* *}$ & $\mathbf{0 . 5 6}$ & & & \\
5. IT & 0.02 & $0.17^{*}$ & $0.37^{* *}$ & -0.08 & $\mathbf{0 . 6 2}$ & & \\
6. MT & 0.09 & 0.07 & -0.10 & $0.47^{* * *}$ & 0.05 & $\mathbf{0 . 6 0}$ & \\
7. NVP & 0.03 & 0.09 & $0.15^{*}$ & $0.21^{* *}$ & 0.11 & 0.11 & $\mathbf{0 . 6 8}$ \\
Means & 3.25 & 46.80 & 5.12 & 5.23 & 5.07 & 5.11 & 5.29 \\
Standard deviation & 0.96 & 15.47 & 1.03 & 0.96 & 1.16 & 1.20 & 1.42 \\
\hline
\end{tabular}

${ }^{\mathrm{a}} * p<0.1 ;{ }^{* *} p<0.05$; and ${ }^{* * *} p<0.01 .{ }^{\mathrm{b}} \mathrm{GG}=$ Government guanxi; BG = Business guanxi; $\mathrm{IT}=$ Institutional turbulence; $\mathrm{MT}=$ Market turbulence; NVP $=$ New venture performance. ${ }^{\mathrm{c}}$ Numbers in bold type indicate the square root of the AVE (average variance extracted). 
Table 3. Results of a moderated regression analysis $(n=146)^{\mathrm{a}, \mathrm{b}}$.

\begin{tabular}{|c|c|c|c|c|c|c|c|c|c|c|c|c|c|c|}
\hline & \multicolumn{14}{|c|}{ New Venture Performance } \\
\hline & \multicolumn{2}{|c|}{ Model 1} & \multicolumn{2}{|c|}{ Model 2} & \multicolumn{2}{|c|}{ Model 3} & \multicolumn{2}{|c|}{ Model 4} & \multicolumn{2}{|c|}{ Model 5} & \multicolumn{2}{|c|}{ Model 6} & \multicolumn{2}{|c|}{ Model 7} \\
\hline & $\beta$ & SE & $\beta$ & SE & $\beta$ & SE & $\beta$ & SE & $\beta$ & SE & $\beta$ & & SE & \\
\hline \multicolumn{15}{|c|}{ Control Variables } \\
\hline Firm age & 0.03 & 0.08 & 0.03 & 0.07 & 0.03 & 0.06 & 0.03 & 0.07 & 0.02 & 0.08 & 0.03 & 0.06 & 0.03 & 0.07 \\
\hline Firm size & $0.17 *$ & 0.08 & $0.16 *$ & 0.08 & $0.11 *$ & 0.07 & 0.13 * & 0.08 & $0.13 *$ & 0.07 & $0.14 *$ & 0.07 & $0.12 *$ & 0.07 \\
\hline \multicolumn{15}{|c|}{ Main Effects } \\
\hline GG & & & $0.23 * *$ & 0.07 & $0.23 * *$ & 0.07 & $0.22 * *$ & 0.06 & $0.21 * *$ & 0.07 & $0.22 * *$ & 0.07 & $0.20 * *$ & 0.08 \\
\hline BG & & & $0.45^{* * *}$ & 0.07 & $0.47^{* * *}$ & 0.07 & $0.46^{* * *}$ & 0.08 & $0.42^{* * *}$ & 0.10 & $0.44^{* * *}$ & 0.09 & $0.39 * * *$ & 0.08 \\
\hline IT & & & $0.17^{*}$ & 0.06 & 0.16 * & 0.06 & 0.15 * & 0.07 & 0.16 * & 0.08 & 0.16 * & 0.07 & 0.13 * & 0.07 \\
\hline MT & & & -0.04 & 0.07 & -0.05 & 0.06 & -0.04 & 0.07 & -0.06 & 0.07 & -0.05 & 0.06 & -0.07 & 0.06 \\
\hline \multicolumn{15}{|c|}{ Two-Way Interactions } \\
\hline $\mathrm{GG} \times \mathrm{IT}$ & & & & & -0.08 & 0.08 & & & & & & & -0.07 & 0.09 \\
\hline $\mathrm{GG} \times \mathrm{MT}$ & & & & & & & $-0.13^{*}$ & 0.07 & & & & & $-0.16^{*}$ & 0.09 \\
\hline $\mathrm{BG} \times \mathrm{IT}$ & & & & & & & & & 0.01 & 0.08 & & & 0.02 & 0.08 \\
\hline $\mathrm{BG} \times \mathrm{MT}$ & & & & & & & & & & & $0.18 *$ & 0.08 & $0.22 * *$ & 0.10 \\
\hline$F$ & \multicolumn{2}{|c|}{$1.32 * *$} & \multicolumn{2}{|c|}{$4.76^{* * *}$} & \multicolumn{2}{|c|}{$4.56^{* * *}$} & \multicolumn{2}{|c|}{$4.28 * * *$} & \multicolumn{2}{|c|}{$4.48^{* * *}$} & \multicolumn{2}{|c|}{$5.67 * * *$} & \multicolumn{2}{|c|}{$4.82 * * *$} \\
\hline $\mathbf{R}^{2}$ & \multicolumn{2}{|c|}{0.05} & \multicolumn{2}{|c|}{0.18} & \multicolumn{2}{|c|}{0.17} & \multicolumn{2}{|c|}{0.16} & \multicolumn{2}{|c|}{0.17} & \multicolumn{2}{|c|}{0.22} & \multicolumn{2}{|c|}{0.18} \\
\hline Adjusted $\mathbf{R}^{2}$ & \multirow{2}{*}{\multicolumn{2}{|c|}{0.04}} & \multirow{2}{*}{\multicolumn{2}{|c|}{$\begin{array}{l}0.16 \\
0.13\end{array}$}} & \multirow{2}{*}{\multicolumn{2}{|c|}{$\begin{array}{l}0.15 \\
0.01\end{array}$}} & \multirow{2}{*}{\multicolumn{2}{|c|}{$\begin{array}{l}0.13 \\
0.01\end{array}$}} & \multirow{2}{*}{\multicolumn{2}{|c|}{$\begin{array}{l}0.14 \\
0.01\end{array}$}} & \multirow{2}{*}{\multicolumn{2}{|c|}{0.19}} & \multicolumn{2}{|c|}{0.16} \\
\hline$\Delta R^{2}$ & & & & & & & & & & & & & 0. & \\
\hline
\end{tabular}

${ }^{\mathrm{a}}$ GG = Government guanxi; BG = Business guanxi; IT = Institutional turbulence; MT = Market turbulence. ${ }^{\mathrm{b} *} p<0.10 ;{ }^{* *} p<0.05 ;{ }^{* * *} p<0.01$. 
Table 3 reports the MHLRA results. As shown in Model 1, new venture performance was not influenced by firm age $(\beta=0.03, \mathrm{~T}=0.35, p>0.1)$ but related to firm size $(\beta=0.17, \mathrm{~T}=2.47, p<0.1)$. However, control variables accounted for only $5 \%$ of the total variance in outcome variables. Model 2 showed that both government guanxi $(\beta=0.23, \mathrm{~T}=3.12, p<0.05)$ and business guanxi $(\beta=0.45$, $\mathrm{T}=6.31, p<0.01)$ had positive effects on new venture performance, providing support for $\mathrm{H} 1$ and $\mathrm{H} 2$, respectively. Business guanxi played a more salient role $(0.23<0.45)$ in strengthening new venture performance than government guanxi. This suggests that, to some extent, new ventures and their founders should invest more resources in developing and maintaining high-quality guanxi connections to the business sectors. This is because resources, information, and technologies obtained from the market are likely to help new ventures embed themselves in the business network and thus build legitimacy for industrial divisions. $\mathrm{H} 3, \mathrm{H} 4, \mathrm{H} 5$, and $\mathrm{H} 6$ considered the moderating effects of two typical environment conditions on performance implications of guanxi. According to Model 3, GG $\times$ IT had no significant interaction effect $(\beta=-0.08, \mathrm{~T}=1.04, p>0.1$ ), providing no support for $\mathrm{H} 3$; Model 4 shows that GG $\times$ MT had a significant negative interaction effect $(\beta=-0.13, \mathrm{~T}=2.07, p<0.1)$, providing support for H4; Model 5 indicates that BG $\times$ IT had no significant interaction effect $(\beta=0.01$, $\mathrm{T}=0.2, p>0.1$ ), providing no support for $\mathrm{H} 5$; and, according to Model 6 , $\mathrm{BG} \times \mathrm{MT}$ had a significant positive interaction effect $(\beta=0.18, \mathrm{~T}=2.62, p<0.1)$, providing support for $\mathrm{H} 6$. The result of the full model (Model 7) was consistent with those of the four separate models, suggesting a high robustness of the research results.

\section{Discussion}

In China's transition economy, the manner in which different types of guanxi can be managed and leveraged more effectively is an emerging topic in the business strategy and entrepreneurship literature. Two pairs of variables (government guanxi versus business guanxi and market turbulence versus institutional turbulence) potentially reflecting the period and nature of a transition economy were included in the analysis. The purpose of this study is to answer the questions of whether both government guanxi and business guanxi are related to new venture performance and when they matter to new venture performance in a rapidly changing environment. The results from 146 new ventures belonging to government-driven high-tech clusters suggest that, in general, both government guanxi and business guanxi can strengthen firm performance. Consistent with the findings of previous studies [2,21,23], the present study also verifies that guanxi remains an important strategic asset with a significant effect on doing business in China's transition economy. In addition, the study examines the moderating effects of institutional turbulence and market turbulence on the relationship between government guanxi (or business guanxi) and new venture performance. The results suggest that a turbulent market environment may weaken the value of government guanxi and strengthen the value of market guanxi. However, the results reveal no moderating effects of institutional turbulence on direct relationships.

\subsection{Findings}

The results can be summarized as follows: First, government guanxi matters to new venture performance. Previous studies have argued that government guanxi may be more important to state-owned enterprises than non-state-owned ones [14]. This study extends the conceptual framework of guanxi in the literature by suggesting that government guanxi is also crucial for new ventures belonging to government-driven high-tech clusters. The primary reason is that the Chinese government has greater "soft power" (through policies) to regulate the emergence and development of industries during an economic transition period [52]. Similarly, Li et al. [12] argued that in emerging economies such as Russia, Latin American, and China, organizational or personal connections to the government can "substitute for formal institutional support." This suggests that new ventures should establish and maintain formal or informal government guanxi to obtain more institutional or policy support from 
the government, ultimately enriching their resource base for better performance. In addition, stronger government guanxi can help new ventures be more confident in doing business in China.

Second, the results verify the significant effect of business guanxi on new venture performance. It is widely acknowledged that firms can benefit from their business guanxi, including guanxi connections to primary customers [10], suppliers [34], and partners [53]. On the one hand, stronger business guanxi can help new ventures establish legitimacy and embed in the business network more quickly, ultimately reducing their liability of newness. On the other hand, it can help new ventures obtain resources and information from the business sector and develop various firm-level capacities to strengthen their business performance.

Third, the empirical results indicate that institutional turbulence had no moderating effect on the relationship between government guanxi (or business guanxi) and new venture performance. A possible explanation may be that, unlike general government policies, those policies concerning government-driven high-tech clusters are relatively stable, and the role of government guanxi in firm performance is rarely influenced by institutional turbulence. Another explanation is that there is a time gap between institutional changes and their effects on the business sector. As a result, for new ventures, business guanxi may not be sensitive to a turbulent environment, and its role in performance creation may be more sensitive to institutional changes [10]. Therefore, institutional turbulence may not influence the performance value of guanxi.

Fourth, the empirical results suggest that market turbulence is an important contingent factor shaping the performance value of guanxi. In a turbulent market environment, rapid changes in customer demands, higher price sensitivity, and stronger ability to exploit new customers may result in greater business challenges and opportunities. If new ventures build and maintain stronger guanxi connections to the government and its officials in a turbulent market environment, it may reduce their resource investment in the market and thus weaken business performance [10]. By contrast, stronger guanxi connections to the business sector may help new ventures exchange resources or information with their primary customers, suppliers, and partners and predict customer and market changes more effectively and quickly in a turbulent market environment, ultimately promoting high-quality products to meet customer demands. This indicates that market turbulence may enhance the performance value of new ventures' stronger guanxi connections to the business sector.

\subsection{Theoretical Contributions}

This study makes several important contributions to the theoretical development of guanxi strategy theory. First, the study enriches guanxi strategy theory by linking two important types of guanxi (government guanxi and business guanxi) and arguing that, in general, both are crucial for the survival and success of new ventures in China's transition economy. However, the roles of two types of guanxi in developing strategic competitiveness are distinct in that they provide different resources for doing business in China [10,54]. Government guanxi is more likely to help new ventures obtain political support or institutional confidence in doing business in China, whereas business guanxi tends to help new ventures access market-related resources such as market information, technological assets, and even potential customers. Furthermore, this study provides new insights into differences in effects of relationships between business guanxi and new venture performance and between government guanxi and new venture performance.

Second, the results also have important implications for social network theory about Chinese entrepreneurship and business operations. Although some studies have argued that weaker social ties play a critical role in job hunting [55], the results provide the opposite conclusion and suggest that strong ties may have vital influence on new venture performance. A possible explanation may be that stronger guanxi ties in China's transition period may help new ventures create a distinct access routine to obtain social capital, thereby contributing to doing business in China.

Third, this study extends the contingent view that the effect of guanxi on new venture performance varies across different turbulent environmental conditions. More specially, two typical environmental 
conditions (institutional turbulence and market turbulence) were set as contextual factors potentially influencing the performance value of government guanxi (or business guanxi). In the contingent model, the empirical results suggest that institutional turbulence may not be a moderator of the guanxi-performance relationship but that market turbulence may weaken or strengthen the relationship.

\subsection{Managerial Implications}

The results offer some useful insights into how government guanxi and business guanxi can be better used in a turbulent environment. First, new ventures can benefit from establishing and developing guanxi connections to the government and its officials or to the business sector. To stimulate regional economic growth and technological progress, the local government often provides various institutional support to new ventures. In particular, in comparison to other new ventures, those belonging to government-driven high-tech clusters may be much more likely to obtain such support from the local government [44]. In addition to government guanxi, business guanxi may help new ventures overcome the liability of newness and obtain important market resources, which play an important role in the success of new ventures.

Second, the results are expected to help entrepreneurs and managers develop more effective policies in response to environmental changes by enhancing different types of guanxi. The interaction between business guanxi and market turbulence had a positive effect on new venture performance, but that between government guanxi and market turbulence had a negative effect. This suggests that new ventures should know that under rapid changes in customer' needs and preferences, they should invest and use business guanxi to make appropriate strategic decisions.

Third, the development and utilization of guanxi may be dynamic and long-term. It indicates that it is not easy to develop guanxi connections with organizations (e.g., business partners and local governments) and people (e.g., managers of other firms and government officials) [56]. Consistent with the findings of Su et al. [25], entering a guanxi network is a difficult strategic conundrum for Hong Kong and Taiwan businessmen, although they have the same Chinese culture. In this regard, entrepreneurs creating new businesses in Mainland China should be aware of the importance of investment in developing and utilizing guanxi which may provide different types of resources.

\subsection{Limitations and Future Research}

As all academic research, this study has some limitations that may provide avenues for further research. First, the outcome indicator of this study was self-reported by the respondents because previous studies of Chinese entrepreneurship have suggested that most new ventures consider financial information as confidential and thus keep it from becoming public. Some Western scholars have also argued that objective and subjective indicators have distinct strengths and weaknesses in measuring new venture performance [40]. In this regard, future research on entrepreneurship should employ a better technique to make simultaneous use of objective and subjective indicators in measuring new venture performance. One possible choice for obtaining objective indicators is to ask for government statistical agency or cluster offices and check whether they can give some useful information about new ventures' survival and success.

Second, the present study followed the social network analysis methodology to quantify guanxi by measuring strong-weak ties of government guanxi (or business guanxi) and investigated their main effects on new venture performance. However, guanxi reflects "networks of informal relationships and exchanges of favors that dominate business activity through China and East Asia" [24]. More specially, quantifying guanxi through a social network analysis proposed by Western scholars may be not the most scientific methodology. In this regard, future research should consider other potential tools to measure guanxi more accurately and deeply in the context of China.

The third limitation of this study is that our sample firms are only from government-driven high-tech clusters. Further research should investigate whether both government guanxi and business 
guanxi also have positive effects on the survival and success of other types of new ventures such as university spin-offs, corporate spin-offs, independent ventures, and born-globals.

Fourth, three indicators (sales growth, market share growth, and employee number growth) were included in measuring new venture performance. However, government guanxi and business guanxi may influence different performance indicators. On the one hand, resources provided by government guanxi tend to be institutional, such as confidence in doing business and less government interference. On the other hand, resources provided by business guanxi tend to be about the market, such as customers making timely payments, low-cost materials, and industrial division benefits [30]. In this regard, further research should empirically tests whether government guanxi is more likely to be related to economic performance (such as market share, market growth, and firm size) and business guanxi is more likely to influence financial performance (such as return on investment, sales, and profit).

\section{Conclusions}

Using a survey sample of 146 new ventures in clusters driven by China's local governments, the present study investigates the relationships among government guanxi, business guanxi, institutional turbulence, market turbulence, and new venture performance. Empirical results suggest that guanxi is a necessary but not sufficient condition for doing business in China. This study argues that the creation of good performance through guanxi must take into account contextual factors such as environmental turbulence. Overall, the study provides a better conceptual and empirical understanding of the importance of guanxi in doing business in China.

Acknowledgments: This research is supported by "Humanity and Social Science Youth Foundation of Ministry of Education of China" (grant No. 14YJC630113); the "China Postdoctoral Science Foundation" (grant No. 2014M561629); the National Natural Science Foundation of China (grant No. 71602090); and "University Entrepreneurship Center Program" of Small and Medium Business Administration (SBMA) of Korea.

Author Contributions: Dejin Su and Dongwon Sohn designed this study and wrote the paper. Qixia Du and Libo Xu conducted the research and analyzed the data. All authors read and approved the manuscript.

Conflicts of Interest: The authors declare no conflict of interest.

\section{References}

1. Chen, C.C.; Chen, X.P.; Huang, S.S. Chinese guanxi: An integrative review and new directions for future research. Manag. Organ. Rev. 2013, 1, 167-207. [CrossRef]

2. Guo, C.; Miller, J.K. Guanxi dynamics and entrepreneurial firm creation and development in China. Manag. Organ. Rev. 2010, 2, 267-291. [CrossRef]

3. Wong, M. Guanxi and its role in business. Chin. Manag. Stud. 2007, 4, 257-276. [CrossRef]

4. Choi, Y.R.; Jin, J.W. Is the web marketing mix sustainable in China? The mediation effect of dynamic trust. Sustainability 2015, 10, 13610-13630. [CrossRef]

5. Fei, X. Shehui Diaocha Zibai (Statement Regarding Social Investigations); Shanghai People's Publishing House: Shanghai, China, 2009. (In Chinese)

6. Choi, Y.R.; Gao, D. The role of intermediation in the governance of sustainable Chinese web marketing. Sustainability 2014, 6, 4102-4118. [CrossRef]

7. Reid, M.F. Institutional preconditions of privatization in market-based political economies: Implications for Jordan. Public Adm. Dev. 1994, 1, 65-77. [CrossRef]

8. Wong, A.; Fang, S.S.; Tjosvold, D. Developing business trust in government through resource exchange in China. Asia Pac. J. Manag. 2012, 4, 1027-1043. [CrossRef]

9. Boso, N.; Story, V.M.; Cadogan, J.W. Entrepreneurial orientation, market orientation, network ties, and performance: Study of entrepreneurial firms in a developing economy. J. Bus. Ventur. 2013, 6, 708-727. [CrossRef]

10. Sheng, S.; Zhou, K.Z.; Li, J.J. The effects of business and political ties on firm performance: Evidence from China. J. Market. 2011, 1, 1-15. [CrossRef] 
11. Banalieva, E.R.; Eddleston, K.A.; Zellweger, T.M. When do family firms have an advantage in transitioning economies? Toward a dynamic institution-based view. Strateg. Manag. J. 2015, 9, 1358-1377. [CrossRef]

12. Li, J.J.; Poppo, L.; Zhou, K.Z. Do managerial ties in China always produce value? Competition, uncertainty, and domestic vs. foreign firms. Strateg. Manag. J. 2008, 4, 383-400. [CrossRef]

13. Cao, Q.; Baker, J.; Schniederjans, D. Bullwhip effect reduction and improved business performance through guanxi: An empirical study. Int. J. Prod. Econ. 2014, 1, 217-230. [CrossRef]

14. Luo, Y.D.; Huang, Y.; Wang, S.L. Guanxi and organizational performance: A meta-analysis. Manag. Organ. Rev. 2012, 1, 139-172. [CrossRef]

15. Luscher, D.; Robins, G.; Pattison, P.E.; Lomi, A. “Trust me”: Differences in ex pressed and perceived trust relations in an organization. Soc. Netw. 2012, 4, 410-424. [CrossRef]

16. Stefano, D.D.; Fuccella, V.; Vitale, M.P.; Zaccarin, S. The use of different data sources in the analysis of co-authorship networks and scientific performance. Soc. Netw. 2013, 5, 370-381. [CrossRef]

17. Wu, K.J.; Liao, C.J.; Tseng, M.L.; Chou, P.J. Understanding innovation for sustainable business management capabilities and competencies under uncertainty. Sustainability 2015, 10, 13721-13760. [CrossRef]

18. Leung, T.K.; Wong, Y.H.; Wong, S. A study of Hong Kong businessmen's perceptions of the role of "guanxi" in the People's Republic of China. J. Bus. Ethics 1996, 7, 749-758. [CrossRef]

19. Chua, R.Y.; Morris, M.W.; Ingram, P. Guanxi vs. networking: Distinctive configuration of affect- and cognition-based trust in the networks of Chinese vs. American managers. J. Int. Bus. Stud. 1996, 3, 490-508. [CrossRef]

20. Chung, H.F.; Yang, Z.L.; Huang, P.H. How does organizational learning matter in strategic business performance? The contingency role of guanxi networking. J. Bus. Res. 2015, 6, 1216-1224. [CrossRef]

21. Park, S.H.; Luo, Y. Guanxi and organizational dynamics: Organizational networking in China firms. Strateg. Manag. J. 2001, 5, 455-477. [CrossRef]

22. Lin, L.H. Cultural and organizational antecedents of guanxi: The Chinese cases. J. Bus. Ethics 2011, 3, 441-451. [CrossRef]

23. Su, D.J.; Sohn, D.W. Roles of entrepreneurial orientation and guanxi network with parent university in start-ups' performance: Evidence from university spin-offs in China. Asian J. Technol. Innov. 2015, 1, 1-19. [CrossRef]

24. Lovett, S.; Simmons, L.C.; Kali, R. Guanxi versus the market: Ethics and efficiency. J. Int. Bus. Stud. 1999, 2, 231-247. [CrossRef]

25. Su, C.T.; Sirgy, M.J.; Littlefield, J.E. Is guanxi orientation bad, ethically speaking? A study of Chinese enterprises. J. Bus. Ethics 2003, 4, 303-312. [CrossRef]

26. Wang, K.J.; Lestari, Y.D. Firm competencies on market entry success: Evidence from a high-tech industry in an emerging market. J. Bus. Res. 2013, 12, 2444-2450. [CrossRef]

27. Chen, M.H.; Chang, Y.Y.; Lee, C.Y. Creative entrepreneurs' guanxi networks and success: Information and resource. J. Bus. Res. 2015, 4, 900-905. [CrossRef]

28. Jackson, M.O. Networks in the understanding of economic behaviors. J. Econ. Perspect. 2014, 4, 3-22. [CrossRef]

29. Peng, M.W.; Luo, Y.D. Managerial ties and firm performance in a transition economy: The nature of a micro-macro link. Acad. Manag. J. 2000, 3, 486-501. [CrossRef]

30. Bu, N.; Roy, J. Guanxi practice and quality: A comparative analysis of Chinese managers' business-to-business and business-to-government ties. Manag. Organ. Rev. 2015, 2, 263-287. [CrossRef]

31. Dacin, M.T.; Oliver, C.; Roy, J. The legitimacy of strategic alliances: An institutional perspective. Strateg. Manag. J. 2007, 2, 169-187. [CrossRef]

32. Huang, W.Y.; Huang, C.Y.; Dubinsky, A.J. The impact of guanxi on ethical perceptions: The case of Taiwanese salespeople. J. Bus. Bus. Market. 2014, 1, 1-17. [CrossRef]

33. Söderblom, A.; Samuelsson, M.; Wiklund, J.; Sandberg, R. Inside the black box of outcome additionality: Effects of early-stage government subsidies on resource accumulation and new venture performance. Res. Policy 2015, 8, 1501-1512. [CrossRef]

34. Joshi, Y.; Rahman, Z. Predictors of young consumer's green purchase behaviour. Manag. Environ. Qual. 2016, 4, 452-472. [CrossRef]

35. Cao, Q.; Simsek, Z.; Jansen, J.J. CEO social capital and entrepreneurial orientation of the firm: Bonding and bridging effects. J. Manag. 2015, 7, 1957-1981. [CrossRef] 
36. Danis, W.M.; Chiaburu, D.S.; Lyles, M.A. The impact of managerial networking intensity and market-based strategies on firm growth during institutional upheaval: A study of small and medium-sized enterprises in a transition economy. J. Int. Bus. Stud. 2010, 2, 287-307. [CrossRef]

37. Jaworski, B.J.; Kohli, A.K. Market orientation: Antecedents and consequences. J. Market. 1993, 3, 53-70. [CrossRef]

38. Su, D.J.; Liu, C.L.; Sohn, D.W. Is deploying a high level of entrepreneurial orientation always crucial for sustainable growth of high-tech ventures? Moderating effects of environmental turbulence. Transylv. Rev. 2016, 9, 1515-1533.

39. Aoun, D. Assessing the economic sustainability of managing protected areas using the CVM and CBA approaches. Manag. Environ. Qual. 2016, 4, 374-389. [CrossRef]

40. Stam, W.; Elfring, T. Entrepreneurial orientation and new venture performance: The moderating role of intra-and extraindustry social capital. Acad. Manag. J. 2008, 1, 97-111. [CrossRef]

41. Sherer, P.D.; Lee, K. Institutional change in large law firms: A resource dependency and institutional perspective. Acad. Manag. J. 2002, 1, 102-119. [CrossRef]

42. Cheng, K.H.; Chiao, Y.C.; Shih, H.Y.; Lee, T.Y.; Cho, T.S. Agglomeration and competition among Chinese cities: An investigation of Taiwanese high-tech foreign direct investment. Growth Chang. 2011, 4, 517-548. [CrossRef]

43. Su, C.T.; Mitchell, R.K.; Sirgy, M.J. Enabling guanxi management in China: A hierarchical stakeholder model of effective guanxi. J. Bus. Ethics 2007, 3, 301-319. [CrossRef]

44. Su, Z.F.; Peng, J.S.; Shen, H.; Xiao, T. Technological capability, marketing capability, and firm performance in turbulent conditions. Manag. Organ. Rev. 2013, 1, 115-137. [CrossRef]

45. Zhang, H. Study on Entrepreneurial Orientation of Multinational Subsidiaries in China: A View of Relational Embeddedness; Economic Science Press: Beijing, China, 2010.

46. Johanson, M. Entering and participating in the turbulent Russian market: Internationalisation as a search and discovery process. J. East-West Bus. 2002, 4, 61-82. [CrossRef]

47. Anderson, B.S.; Eshima, Y. The influence of firm age and intangible resources on the relationship between entrepreneurial orientation and firm growth among Japanese SMEs. J. Bus. Ventur. 2013, 3, 413-429. [CrossRef]

48. Shou, Z.; Chen, J.; Zhu, W.; Yang, L. Firm capability and performance in China: The moderating role of guanxi and institutional forces in domestic and foreign contexts. J. Bus. Res. 2014, 2, 77-82. [CrossRef]

49. Bagozzi, R.P.; Yi, Y. On the evaluation of structural equation models. J. Acad. Market. Sci. 1988, 1, 74-94. [CrossRef]

50. Barrick, M.R.; Bradley, B.H.; Kristof-Brown, A.L.; Colbert, A.E. The moderating role of top management team interdependence: Implications for real teams and working groups. Acad. Manag. J. 2007, 3, 544-557. [CrossRef]

51. Gajendran, R.S.; Joshi, A. Innovation in globally distributed teams: The role of LMX, communication frequency, and member influence on team decisions. J. Appl. Psychol. 2012, 6, 1252-1261. [CrossRef] [PubMed]

52. Lee, D.J.; Pae, J.H.; Wong, Y.H. A model of close business relationships in China (guanxi). Eur. J. Market. 2001, 35, 51-69. [CrossRef]

53. Beck, M.; Schenker-Wicki, A. Cooperating with external partners: The importance of diversity for innovation performance. Eur. J. Int. Manag. 2014, 5, 548-569. [CrossRef]

54. Li, H.Y.; Zhang, Y. The role of managers' political networking and functional experience in new venture performance: Evidence from China's transition economy. Strateg. Manag. J. 2007, 8, 791-804. [CrossRef]

55. Granovetter, M. Economic action and social structure: A theory of embeddedness. Am. J. Sociol. 1985, 3, 481-510. [CrossRef]

56. Zhang, Y.; Zhang, Z. Guanxi and organizational dynamics in China: A link between individual and organizational level. J. Bus. Ethics 2006, 4, 375-392. [CrossRef]

(C) 2017 by the authors; licensee MDPI, Basel, Switzerland. This article is an open access article distributed under the terms and conditions of the Creative Commons Attribution (CC BY) license (http:/ / creativecommons.org/licenses/by/4.0/). 